\title{
COOPERATION BETWEEN HEAD TEACHERS AND PROFESSIONAL SCHOOL COUNSELLORS IN SLOVENIAN SCHOOLS
}

\author{
Petra Gregorčič Mrvar* \\ Metod Resman ${ }^{* *}$ \\ Jana Kalin ${ }^{* * *}$ \\ Jasna Mažgon ${ }^{* * * *}$
}

Received: 27.6. 2018

Preliminary communication

Accepted: 30. 1. 2019

UDC 37.07

DOI https://doi.org/10.30924/mjcmi.24.si.6

\begin{abstract}
The characteristics of cooperation between head teachers and school counsellors are presented theoretically and empirically. Distributed leadership means that head teachers do not lead schools through school-based educators but rather together with them, with school counsellors playing an important role. Numerous research studies demonstrate that a strong head teacher-school counsellor relationship is a crucial component of meeting the vision, goals and well-being of the school. The findings of our research study, conducted among head teachers and school counsellors, show positive attitudes of both groups towards mutual cooperation. Both considered the cooperation to be good or very good, the head teachers rated it even better. It is interesting to observe that the head teachers
\end{abstract}

found more support in school counsellors than vice versa. Also, more of the head teachers said they saw school counsellors as partners than did the school counsellors. It thus remains to be seen how school counsellors' perception of the school leadership's support in their work could be strengthened and how head teachers could be encouraged to support the work of the school counselling service even more, so that this relationship becomes reciprocal and that each party's ability to perform their work will be enhanced by the strong relationship.

Keywords: distributed leadership, head teacher, school counsellor, pedagogues, cooperation

\footnotetext{
"Petra Gregorčič Mrvar, Assistant Professor, Faculty of Arts - University of Ljubljana, Department of Educational Sciences, Aškerčeva 2, 1000 Ljubljana, Slovenia, Phone: +386 124111 42, E-mail: Petra.GregorcicMrvar@ff.unilj.si

${ }^{* *}$ Metod Resman, Full Professor, Faculty of Arts - University of Ljubljana, Department of Educational Sciences, Aškerčeva 2, 1000 Ljubljana, Slovenia, E-mail: metod.resman@guest.arnes.si

*** Jana Kalin, Full Professor, Faculty of Arts - University of Ljubljana, Department of Educational Sciences, Aškerčeva 2, 1000 Ljubljana, Slovenia, E-mail: jana.kalin@guest.arnes.si

***** Jasna Mažgon, Associate Professor, Faculty of Arts - University of Ljubljana, Department of Educational Sciences, Aškerčeva 2, 1000 Ljubljana, Slovenia, E-mail: jasna.mazgon@ff.uni-lj.si
} 


\section{Journal of Contemporary Management Issues}

\section{INTRODUCTION}

In many countries decentralisation in education means that schools have become more autonomous and they are held more accountable for their students' and the school's outcomes (2007; Pont et al., 2008). In the circumstances that give schools more autonomy and in which work quality largely depends on schools, head teachers' work, in particular, has become extremely complex and varied (Pont et al., 2008; Schleicher, 2015). Leadership is becoming an increasingly valued and shared phenomenon at the school level (Stone and Clark, 2001), and its understanding has changed from leading "people" to leading "together with people".

Although leadership begins with the head teacher, it should also include other players, such as school counsellors, teachers, parents, students and community members who contribute to making schools even better (Stone and Clark, 2001). It is important that debates on leadership and management in education focus on those schoolbased educators who assume leadership together with the head teacher when their school is faced with any number of issues of school life and work. One of the most important roles is played by school counsellors (Stone and Clark, 2001; Resman, 2004; Wingfield et al., 2010) ${ }^{1}$.

This article presents a number of aspects of cooperation between head teachers and school counsellors. The first part of the article sketches the position and tasks of head teachers and school counsellors, as well as some of the aspects of their mutual cooperation. The second part presents the findings of the empirical study we conducted among head teachers and school counsellors in Slovenian schools at the beginning of 2018 . The study examined the views and assessments of school counsellors and head teachers of their mutual cooperation. In Slovenia, there has been no representative research study of cooperation between head teachers and school counsellors since the 1990s (see Resman et al., 1999). Internationally, such studies have become widespread in the last decade (cf. e.g. Finkelstein, 2009; Edwards et al., 2014; Duslak and Geier, 2016).

\subsection{The position and tasks of the head teacher}

The position and tasks of head teachers in Slovenia have changed just as they have changed internationally (cf. Eurydice, 2007). Nowadays, head teachers have more specifically defined (formal, stated) tasks, which means more accountability to the state on the one hand and more moral responsibility towards teachers, students, parents and the local community on the other (cf. McCarty et al., 2014; Greene and Stewart, 2016). According to Slovenian law, head teachers' responsibilities consist of both managerial (administrative) and pedagogical leadership (Zakon o organizaciji... 2017, Article 49). Managerial leadership consists of dealing with finances, recruitment, salaries and numerous regulations and norms. As pedagogical leaders, head teachers build and strengthen relationships with employees, they motivate them,

\footnotetext{
The school counselling service is specific to Slovenian schools. However, Croatia has the same system. International comparison (Bela knjiga ..., 2011) demonstrates that only a very small number of countries have school-based counsellors employed by the school. In most countries school counselling is carried out by external services or experts working in external professional services (e.g. counselling centres, educational, pedagogical and psychological or mental-hygienic counselling centres, etc.), which are mostly organised locally or in bigger towns, looking after a number of schools. They have a (widespread) network of services outside educational institutions. However, some countries, for instance Sweden, Norway, Estonia, Poland, the UK, have started considering, in recent years, to employ school counsellors at schools (ibid., p. 481).
} 
guarantee high-quality educational processes, create supportive school atmosphere, cooperate with parents and the community and follow the school's vision (ibid.; Dolgan, 2012). However, pedagogical leadership is not merely working with people; it also requires guaranteeing suitable conditions for educational work and successful planning, which includes planning the development of employees (Hopkins, 2000, in Dolgan, 2012). In addition, head teachers cannot ignore changes in society, or increased social problems in the environment (Hertling, 2001; Edwards et al., 2014), the expectations expressed by teachers, students, parents, state and local authorities, the local community (McCarty et al., 2014); also, there is lots of paperwork, administrative tasks, etc.

This makes head teachers' position an unenviable one; indeed, they are faced with very complex tasks and situations (cf. Harris, 2008; Schleicher, 2015). If head teachers cannot reduce the pressures, they will burn themselves out, and increased fluctuation is very likely. Making and retaining a good head teacher will prove to be ever more challenging - a head teacher who will ensure the school's and its participants' effectiveness and quality through suitable (distributed) leadership.

Internationally, distributed leadership is among the most effective approaches to leading educational institutions in the $21^{\text {st }}$ century (cf. Harris, 2002, 2008; Pont et al., 2008). Distributed leadership is characterised as a form of collective leadership in which educators develop expertise by working collaboratively (Harris, 2002). It is a form of leadership where the practice of leadership is shared amongst organisational members (Harris, 2008). Here organisational influence and decision-making is governed by the interaction of individuals rather than individual direction (ibid.).
This distributed view of leadership requires schools to "de-centre" the leader (Gronn, 2002, in Harris, 2002). The role of those in formal leadership positions - head teachers in our case - is primarily to hold the pieces of the organisation (school) together in a productive relationship (Harris, 2002, 2008). According to a Slovenian research study (Dolgan, 2012), primary-school head teachers mainly demonstrate the cooperative leadership style, which implies encouraging the staff to reflect, taking account of their views, suggestions and prior knowledge, views and ideas.

Head teachers should not lead schools through educators, but rather together with them. Such leadership relies on the participation of all employees when planning the school's goals, visions and development and when solving problems. The development and maintenance of a cooperative school atmosphere is encouraged. Thus, staff members often communicate, observe and assess one another and plan work together. This encourages them to learn from one another about how to work better. It increases teachers' motivation for work and gives them opportunities for professional growth.

If we agree that "two heads are better than one" and that jointly we can achieve more than each individual on their own, then it is clear that we cannot do without teamwork (Gregorčič Mrvar and Resman, 2013; McCarty et al., 2014). Head teachers should believe that in teamwork educators can find better solutions than they could do alone. Head teachers should believe that they will think about issues, that they will be able to analyse and define the problem as well as choose among alternatives. It will boost their confidence and professional responsibility. This is the context that gives school-based counsellors special prominence. 


\subsection{The position and tasks of the school counsellor}

In Slovenia, the school counselling service is one of the subsystems of a school, so its primary goal is determined by the primary goal of the school. Different experts (e.g. pedagogues, psychologists, social workers, social pedagogues, special pedagogues, etc.) work in the school counselling service. It is an interdisciplinary professional school service, participating in solving complex pedagogical, psychological and social issues in schools, concerning everybody attending them or working there.

According to Resman (1999, pp. 6869) and the Programme guidelines for the school counselling service (Programske smernice ..., 2008), school-based counselling work, as conceptualised in Slovenia, has never been limited only to assisting students in their personal development and learning. As such, it provides not only student counselling, directly helping students with their development, but it also helps indirectly the functioning of the school counselling service in terms of planning, implementing and evaluating everyday educational work in schools, as well as planning, creating and maintaining favourable conditions for a safe and encouraging educational environment that allows students optimum progress (Programske smernice ..., 2008). In this area the professional school counsellor's role and work primarily relate to the (pedagogical) leadership of the school and collaboration with the head teacher. The role of school counsellors as school leaders has been examined by a number of international authors (e.g. Stone and Clark, 2001; Wingfield et al., 2010; Edwards et al.,
2014), and it has been the subject of many studies in the last decade (e.g. Duslak and Geier, 2016; Bryan et al., 2018).

School counsellors' work in Slovenian schools, especially the work of pedagogues ${ }^{2}$ (cf. Resman et al., 2000), among others (e.g. counselling work with students, consultation work with teachers, etc.), includes the methodology of planning, conducting, monitoring and evaluating the educational process and the work of the entire school, group activities, programmes, various target groups and, through that, the solution of individual, group and other complex issues and problems of the school. This is the context, in which professional school counsellors collaborate with the head teacher to create the school's vision and development plan, the school's annual work plan, the school's educational concept, to draw up school rules, etc.

The starting point for planning, carrying out and evaluating the presented plans and concepts should be related to the comprehensive system of quality assurance in the educational institution and the school's self-evaluation (cf. Podgornik and Vogrinc, 2017). School counsellors - pedagogues evaluate comprehensively and critically the quality of the educational institution, primarily in terms of guaranteeing an encouraging learning environment for an optimum development of each student.

In this respect school counsellors are initiators of professional (organisation and content) bases for the development of school teams and team culture (Gregorčič Mrvar and Resman, 2013). Here, the area of their work is linked to the study of and

\footnotetext{
2 To work as a professional school counsellor, pedagogues must complete the Master programme, which states that they gained high-quality humanities and social sciences education with an emphasis on the systematic study of educational sciences; they are irreplaceable in some areas of work of an educational institution. They have knowledge of the scientific paradigms and orientations relevant to the understanding of educational processes and interactions among educational events, processes and society.
} 
change in the educational institution's culture and climate, including the implementation of the concept of inclusive education (Jeznik et al., 2018; Lesar, 2018). Finally, it is important to emphasise professional school counsellors' contribution to cooperation with cultural, sport, charity, expert institutions and initiatives in the local environment and to cooperation with parents (Gregorčič Mrvar and Mažgon, 2017; Šteh et al., 2018). School counsellors - pedagogues - should consider the work of the entire educational institution, cooperate with parents, external experts and institutions so that the work and life in the institution and classes improve for the benefit of the entire student population (Resman, 2004).

\subsection{Cooperation between head teachers and school counsellors}

Head teachers can take steps towards distributed leadership if they have enough qualified and motivated employees to take on responsibility for co-creating the school's image, which is, formally speaking, the head teacher's responsibility. In terms of their mission these educators certainly include school counsellors (Stone and Clark, 2001; Resman, 2004; Wingfield et al., 2010). Whether head teachers become aware of the opportunities or not, to what degree and how they engage school counsellors depends on both head teachers and school counsellors.

Head teachers and school counsellors both endeavour to ensure optimum development of all students, achievements as high as possible and high quality work of the entire school, which are all the main reasons for their cooperation (cf. Stone and Clark, 2001; Edwards et al., 2014; McCarty et al., 2014; Duslak and Geier, 2016). In addition to the advantages and benefits, related to students' and the school's development, quality relationship enriches head teachers and school counsellors, too. Such cooperation benefits all participants, for example, strong relationships enhance role understanding, prevent burnout, etc. (cf. Wingfield et al., 2010; Edwards et al., 2014; Duslak and Geier, 2016).

Their cooperation, debates and agreements surpass the partiality of one or the other. Although their debates relate to a specific problem or an individual case, they always see, assess and solve it from the school's aspect. While the head teacher focuses on the school's organisational and systemic problems, the school counsellor mostly takes account of students and teachers as well as the educational aspects of school work (cf. Armstrong et al., 2010; Greene and Steward, 2016).

The school counsellor's position, role and programme greatly depend on how the school understands the role of school counsellors, what the head teacher expects, what the school vision is and the leadership style. The head teacher's leadership orientation defines the responsibilities that are assigned to the school counsellor.

Researchers have suggested that a strong, high-quality relationship between head teachers and school counsellors helps head teachers understand school counsellors' role better, which may lead to greater programmatic and vision alignment, better quality educational work and higher student achievement (Dahir et al., 2011, in Duslak and Geier, 2016; Edwards et al., 2014). If head teachers are not familiar with or lack understanding of school counsellors' tasks, they may delegate tasks to them that are outside their professional expertise and their work or programme (Armstrong et al., 2010; Edwards et al., 2014).

In the relationship between head teachers and professional school counsellors, 
much research has studied the factors influencing relationship quality (cf. Finkelstein, 2009; Duslak and Geier, 2016). These determinants include trust, confidence, clear and open communication, cooperation, support, a shared vision, role understanding and positive regard, distributed leadership, knowledge, empathy and respect (cf. ibid.). It transpires that relationship quality mostly depends on mutual communication, respect, mutual understanding of roles and responsibilities and trust. These are the bases for good cooperation and quality development.

Studies about the factors of strong head teacher-counsellor relationships addressed communication frequency between school counsellors and head teachers, supporting the counsellor's role, counsellors advocating for their programme and working towards building a relationship with head teachers, differences between primaryschool and secondary-school counsellors' perceptions of their relationships with head teachers and components of the head teacher-school counsellor relationship (cf. ibid.). In their study, Duslak and Geier (2016) found that more frequent meetings were associated with higher ratings of relationship quality but the meetings do not need to be formalised in order to be effective.

Mutual cooperation, however, may be faced with obstacles, for instance disagreement between professional school counsellors and head teachers regarding the duties of the school counsellor, perceptions of the roles and responsibilities of school counsellors, time for cooperation, etc. (Janson et al., 2008; Finkelstein, 2009; Wingfield et al., 2010). Any obstacles to mutual cooperation should be identified, accepted, understood and systematically overcome. This is enabled by evaluating recent mutual cooperation, which will assess individuals' viewpoints, actions as well as the (in)effectiveness of the cooperation. The more head teachers and school counsellors know and understand the characteristics (peculiarities) of each other's work and tasks as well as attitudes towards and expectations from cooperation, the more successful their cooperation is likely to be (McCarty et al., 2014).

\section{THE AIM OF THE RESEARCH STUDY}

We studied aspects of cooperation between head teachers and school counsellors in a comprehensive empirical research study conducted from January to March 2018. The study included school counsellors, students, teachers, head teachers and parents from Slovenian primary and secondary schools. We were interested in how the school counselling service functions in Slovenian schools today and how school counsellors cooperate with different school participants. This article only deals with the research questions that related to cooperation between head teachers and school counsellors in Slovenian primary and secondary schools, namely:

1. What were the head teachers' and the school counsellors' overall assessments of their mutual cooperation?

2. What were the head teachers' and the school counsellors' assessments of the individual aspects of their mutual cooperation?

3. What were the head teachers' and the school counsellors' assessments of the individual forms of their mutual cooperation?

4. What were the head teachers' and the school counsellors' assessments of the obstacles they encountered during their mutual cooperation? 


\section{METHODOLOGY}

\subsection{Research methods and the sample}

The descriptive and causal non-experimental method was used for the research (Sagadin, 2004). The school counsellors' sample included 315 individuals from Slovenian primary and secondary schools, the majority were women (305, i.e. $96.8 \%)$ and only 10 were men (3.2\%). Their average age was 44.9 years and their average length of service in education was 16.62 years. In terms of professional profiles, the majority were pedagogues $(42.4 \%)$, a good quarter were psychologists $(28.3 \%)$, with other profiles in smaller shares (social workers $-14.6 \%$, social pedagogues $10.5 \%$, special pedagogues $-2.5 \%$ and others $-1.6 \%)$.

In the head teachers' sample of 266 persons, the majority (212 or $79.7 \%$ ) worked in primary schools and a much smaller share (46 or $17.3 \%$ ) worked in secondary schools. Eight head teachers (3\%) from our sample worked in primary schools for children with special needs. The average length of service in the position of the head teacher was 10.5 years and the average number of students in their schools was 409. On average, the schools whose head teachers were included in our sample employed 1.7 school counsellors.

\subsection{Data gathering and research instruments}

In January 2018 all the head teachers and school counsellors in Slovenian primary schools $(\mathrm{N}=454)$ and secondary schools $(\mathrm{N}=182)$ were sent an email with links to two questionnaires, one for the head teachers and one for the school counsellors.

The recipients of the email were given access via a link to an anonymous questionnaire which they completed and submitted online. The questionnaire contained a set of demographic questions (gender, education, professional profile, number of years employed in education, number of years in the position of the head teacher, whether they worked in a primary or secondary school, region). The questionnaire contained a Likert scale, single and multiple response questions and open questions. For the purposes of this article, we present findings related to the attitudes of the head teachers and school counsellors on specific aspects of mutual cooperation (6 statements) and their assessments of different forms of cooperation (5 statements) measured on a Likert scale. Respondents used a five-point scale to express their level of agreement or disagreement with individual statements. For the assessment of obstacles (6 statements) a four-point rating scale was used. Statistical analysis showed that the scales were reliable (Cronbach's coefficient $\alpha \geq 0.80$ ) and valid (the first factor explained $20 \%$ of the variance).

\subsection{Data analysis}

The data is presented in frequency and structural tables, for some variables the mean value and the standard deviation were calculated. The hypotheses of independence were tested by Pearson Chi-Square test and Likelihood Ratio Chi-Square test, in cases when the expected counts were too low (more than 20\%) to meet the criteria for the use of the Pearson Chi-Square test. The null hypotheses were tested by using the independent t-test.

\section{FINDINGS AND INTERPRETATION}

First we were interested in the overall assessments of the mutual cooperation between school counsellors and head teachers. 
Journal of Contemporary Management Issues

Table 1: The head teachers' and the school counsellors' overall assessments

of their mutual cooperation

\begin{tabular}{|c|c|c|c|c|c|c|}
\hline \multirow[b]{2}{*}{ School role } & \multicolumn{5}{|c|}{$\begin{array}{l}\text { What is your overall assessment of your cooperation with the } \\
\text { school counselling service/head teacher? }\end{array}$} & \multirow[b]{2}{*}{ Total } \\
\hline & $\begin{array}{l}\text { Very } \\
\text { good }\end{array}$ & Good & $\begin{array}{l}\text { Neither } \\
\text { good nor } \\
\text { bad }\end{array}$ & Poor & $\begin{array}{l}\text { Very } \\
\text { poor }\end{array}$ & \\
\hline Head teachers & $\begin{array}{l}168 \\
67.5 \%\end{array}$ & $\begin{array}{l}69 \\
27.7 \%\end{array}$ & $\begin{array}{l}9 \\
3.6 \%\end{array}$ & $\begin{array}{l}3 \\
1.2 \%\end{array}$ & $\begin{array}{l}0 \\
0.0 \%\end{array}$ & $\begin{array}{l}249 \\
100.0 \%\end{array}$ \\
\hline $\begin{array}{l}\text { School } \\
\text { counsellors }\end{array}$ & $\begin{array}{l}153 \\
51.2 \%\end{array}$ & $\begin{array}{l}99 \\
33.1 \%\end{array}$ & $\begin{array}{l}36 \\
12.0 \%\end{array}$ & $\begin{array}{l}6 \\
2.0 \%\end{array}$ & $\begin{array}{l}5 \\
1.7 \% \\
\end{array}$ & $\begin{array}{l}299 \\
100.0 \%\end{array}$ \\
\hline Total & $\begin{array}{l}321 \\
58.6 \%\end{array}$ & $\begin{array}{l}168 \\
30.7 \%\end{array}$ & $\begin{array}{l}45 \\
8.2 \%\end{array}$ & $\begin{array}{l}9 \\
1.6 \%\end{array}$ & $\begin{array}{l}5 \\
0.9 \%\end{array}$ & $\begin{array}{l}548 \\
100.0 \%\end{array}$ \\
\hline
\end{tabular}

$\chi^{2}=26.817(\mathrm{~g}=4 ; \alpha=.000)$

Quality school work crucially depends on how the participants perceive mutual cooperation, how they agree on distributing tasks and responsibilities, which responsibilities are accepted by head teachers and which by school counsellors.

As the result of the Chi-Square test shows, the difference in the overall assessment of cooperation between the head teachers and the school counsellors is statistically significant $(\alpha=.000)$. The figures in Table 1 indicate that more than two thirds of the head teachers $(67.5 \%)$ assessed their cooperation with the school counselling service as very good, whereas only a good half of the school counsellors described their cooperation with head teachers as such. The figures also show that a relatively high share $(12 \%)$ of the school counsellors described their cooperation with school counsellors as neither good nor bad. Only few head teachers and school counsellors stated that their mutual cooperation was poor or very poor.

The findings suggest that the head teachers were more satisfied with cooperation between themselves and the school counselling service than the school counsellors. This was to be expected. The results indicate that the school counsellors wanted a closer cooperation with head teachers. On the other hand, it would be interesting if they had all assessed their mutual cooperation as very good. Very close cooperation might imply great agreement in all elements, which is likely to weaken the necessary critical distance, and - from the outside, in students' and teachers' eyes - it would appear as "inseparable" closeness. The school counsellor might be perceived as the head teacher's assistant, which could weaken their counselling strength. It is normal that there are exceptions among school counsellors, who are not satisfied at all with their cooperation with head teachers. In these instances school counsellors' fluctuation is more likely.

We then proceeded with the question about what the head teachers' and the school counsellors' assessments were of more specific aspects of their mutual cooperation. Here, we formulated six statements, which the respondents responded to on a 5 -point Likert-type scale. The are given in Table 2. 
Management, Vol. 24, 2019, Special Issue, pp. 89-106 P. Gregorčič Mrvar, M. Resman, J. Kalin, J. Mažgon: COOPERATION BETWEEN HEAD...

Table 2: The head teachers' and the school counsellors' assessments of the individual aspects of their mutual cooperation

\begin{tabular}{|c|c|c|c|c|c|}
\hline $\begin{array}{l}\text { Statements on cooperation between head teachers } \\
\text { and school counsellors* }\end{array}$ & School role & $\mathrm{N}$ & M & SD & $\begin{array}{l}\mathrm{t}-\text { test }^{* *} \\
\alpha\end{array}$ \\
\hline \multirow{2}{*}{$\begin{array}{l}\text { Generally speaking, I cooperate well with the } \\
\text { school counsellors/the head teacher. }\end{array}$} & Head teachers & 249 & 4.59 & .56 & $\mathrm{t}=5.079$ \\
\hline & School counsellors & 297 & 4.30 & .78 & $\alpha=.000$ \\
\hline \multirow{2}{*}{$\begin{array}{l}\text { The school counselling service/the head teacher is } \\
\text { important support in the realisation of my and the } \\
\text { school's work. }\end{array}$} & Head teachers & 248 & 4.46 & .75 & $t=6.937$ \\
\hline & School counsellors & 296 & 3.94 & 1.01 & $\alpha=.000$ \\
\hline \multirow{2}{*}{$\begin{array}{l}\text { School counsellors are authorised to do some } \\
\text { things without the head teacher's knowledge. }\end{array}$} & Head teachers & 248 & 3.97 & .91 & $\mathrm{t}=2.820$ \\
\hline & School counsellors & 295 & 3.73 & 1.03 & $\alpha=.005$ \\
\hline \multirow{2}{*}{$\begin{array}{l}\text { The head teacher gives the school counselling } \\
\text { service freedom; the head teacher lets school } \\
\text { counsellors work in their own way. }\end{array}$} & Head teachers & 247 & 3.59 & .87 & $\mathrm{t}=3.571$ \\
\hline & School counsellors & 296 & 3.86 & .88 & $\alpha=.000$ \\
\hline \multirow{2}{*}{$\begin{array}{l}\text { School counsellors see the head teacher as a } \\
\text { partner in solving professional issues at school. } \\
\text { They seek her/his advice on professional issues. }\end{array}$} & Head teachers & 247 & 4.55 & .54 & $\mathrm{t}=8.745$ \\
\hline & School counsellors & 296 & 3.98 & .96 & $\alpha=.000$ \\
\hline \multirow{2}{*}{$\begin{array}{l}\text { As the head teacher I accept some of the measures } \\
\text { proposed by school counsellors. }\end{array}$} & Head teachers & 243 & 4.26 & .53 & $t=6.303$ \\
\hline & School counsellors & 293 & 3.90 & .77 & $\alpha=.000$ \\
\hline
\end{tabular}

* The respondents expressed their agreement or disagreement on the following 5-point scale: 1 - strongly disagree, 2 -disagree, 3 - neither agree nor disagree, 4 -agree, 5 - strongly agree.

** In all the instances the value of Levene's test for the equality of variances was statistically significant, so we used Welch's t-test.

We established that the differences between the two groups were statistically significant for all the statements (Table 2). On average, the head teachers expressed a higher degree of agreement with all the statements, except for the statement The head teacher gives the school counselling service freedom; the head teacher lets school counsellors work in their own way.

Looking at the findings in more detail, we see that both the head teachers and the school counsellors agreed most with the statement Generally speaking, I cooperate well with the school counsellors/the head teacher, which corresponds with the findings presented in Table 1, where the head teachers and the school counsellors both expressed a very high opinion regarding their mutual cooperation.

The biggest differences in the degrees of agreement between the head teachers and the school counsellors were found in the following two statements: The school counselling service/the head teacher is important support in the realisation of my and the school's work and School counsellors see the head teacher as a partner in solving professional issues at school. They seek her/his advice on professional issues. These statements are the foundation of cooperation between head teachers and school counsellors, as they reveal how they perceive support for each other and how they see their partnership. It is noteworthy that the head teachers saw greater support in school counsellors than vice versa. Likewise, more head teachers said that they perceived school counsellors to be their partners than did the school counsellors. As far as "support in the realisation of my and the school's work" is concerned, it would be important to know what profiles of school counsellors the head teachers 
worked with. A theoretical and logical hypothesis may be that not all school counsellors provide the same amount of support. To what degree, then, can different profiles actually support head teachers as the pedagogical leader of the school in, for example, planning, monitoring and evaluating work, in designing the didactic structure and leading the pedagogical regime and developing quality, which is the head teacher's responsibility. In terms of knowledge and competences, the school pedagogue would certainly be a competent collaborator, which is what we have already discussed in the theoretical section of this article (cf. Resman et al., 2000). Therefore, it would be important to examine to what degree the findings above correspond to head teachers' cooperation with individual profiles of school counsellors.

The statement with the lowest degree of agreement was School counsellors are authorised to do some things without the head teacher's knowledge. This emphasises the question as to the level of the school counselling service's autonomy. The findings suggest that the head teachers, according to their own and the school counsellors' views, kept a relatively strict control over their school counselling services, which only rarely took on tasks without head teachers' knowledge. Such considerations would require further insights into what tasks are conducted by school counsellors without head teachers' knowledge and what tasks require head teachers' authorisation. If the tasks are outside head teachers' responsibly, it is understandable that school counsellors need not ask for special authorisation. If a task originates in the school counsellor's work programme that was adopted at the start of the school year, then there is no need for special authorisation. It is also possible that school counsellors know head teachers' views very well, that there is a high degree of trust between them, and so school counsellors do certain tasks without head teachers' knowledge.

But it is also noteworthy that the school counsellors in our study expressed a higher degree of agreement with the statement The head teacher gives the school counselling service freedom; the head teacher lets school counsellors work in their own way. This indicates that the head teachers thought they regulated school counsellors' work more than did the school counsellors themselves. The school counsellors did not perceive such regulation as strongly, and they stated that they were more autonomous in their work. We suggest that, at least here, the school counsellors' views are more relevant - it is significant that they felt autonomous in their professional work. The head teachers' viewpoint denotes their trust in school counsellors' professional work. They allow school counsellors freedom, because they know their views and they know that they work well and to the benefit of everybody in the school. Therefore, they trust them. And trust is a crucial factor influencing relationship quality (cf. Finkelstein, 2009; Duslak and Geier, 2016).

We would also like to emphasise that school counsellors' autonomy does not end with regulation and norms. Rather, it depends on how their cooperation, relationships and knowledge are managed. Head teachers are occasionally forced to limit a school counsellor's autonomy for the benefit of the school, because they are responsible for the work of the entire school. If school counsellors were to try out arbitrarily their ideas and projects without the necessary permissions, head teachers would have to restrict their "autonomy". However, we should have no illusions of all school counsellors using the right to professional autonomy. Some of them prefer to be guided by head teachers, waiting for their 
Management, Vol. 24, 2019, Special Issue, pp. 89-106 P. Gregorčič Mrvar, M. Resman, J. Kalin, J. Mažgon: COOPERATION BETWEEN HEAD...

Table 3: The head teachers' and the school counsellors' assessments of the forms of their mutual cooperation

\begin{tabular}{|c|c|c|c|c|c|}
\hline Statements on cooperation* & School role & $\mathrm{N}$ & M & SD & $\begin{array}{l}\mathrm{t}-\text { test }^{* *} \\
\alpha\end{array}$ \\
\hline \multirow{2}{*}{$\begin{array}{l}\text { I regularly meet with the school counselling } \\
\text { service / the head teacher to discuss the work } \\
\text { finished and planned. }\end{array}$} & Head teachers & 248 & 4.25 & .85 & $\mathrm{t}=6.532$ \\
\hline & School counsellors & 299 & 3.66 & 1.24 & $\alpha=.000$ \\
\hline \multirow{2}{*}{$\begin{array}{l}\text { I often meet with the school counselling service } \\
\text { / the head teacher outside scheduled regular } \\
\text { appointments. }\end{array}$} & Head teachers & 245 & 4.47 & .58 & $\mathrm{t}=6.124$ \\
\hline & School counsellors & 297 & 4.06 & .96 & $\alpha=.000$ \\
\hline \multirow{2}{*}{$\begin{array}{l}\text { When we meet with the school counselling service } \\
\text { / the head teacher, we agree on what needs to be } \\
\text { done, plan together how to do it and share tasks. }\end{array}$} & Head teachers & 246 & 4.19 & .68 & $\mathrm{t}=7.775$ \\
\hline & School counsellors & 297 & 3.60 & 1.07 & $\alpha=.000$ \\
\hline \multirow{2}{*}{$\begin{array}{l}\text { The plan for what needs to be done and how to } \\
\text { do it is drawn up by the head teacher. The head } \\
\text { teacher also decides who will do what. }\end{array}$} & Head teachers & 247 & 2.45 & .89 & $\mathrm{t}=7.235$ \\
\hline & School counsellors & 298 & 3.03 & .98 & $\alpha=.000$ \\
\hline \multirow{2}{*}{$\begin{array}{l}\text { I cooperate with the school counselling service / } \\
\text { the head teacher mainly in boards - together with } \\
\text { the manager, head teachers, assistants, etc. }\end{array}$} & Head teachers & 238 & 2.04 & .91 & $\mathrm{t}=3.688$ \\
\hline & School counsellors & 285 & 2.37 & 1.14 & $\alpha=.000$ \\
\hline
\end{tabular}

* The respondents responded to the statements on the following scale: 1 - not true at all, 2 -not true, 3 - neither true nor untrue, 4 - true, 5 - very true.

** In all the instances (except for the statement The plan for what needs to be done and how to do it is drawn up by the head teacher. The head teacher also decides who will do what.) the value of Levene's test for the equality of variances was statistically significant, so we used Welch's t-test.

initiative. Autonomy, namely, means that school counsellors assume great professional responsibility.

Table 3 shows the head teachers' and the school counsellors' assessments of the forms of their mutual cooperation. The differences between the groups were statistically significant for all five statements. The first three statements in the table were assessed significantly higher by the head teachers; with the last two the picture was inversed.

Looking at the individual statements that described different forms of cooperation reveals that the difference in the statements I regularly meet with the school counselling service / the head teacher to discuss the work finished and planned and When we meet with the school counselling service / the head teacher, we agree on what needs to be done, plan together how to do it and share tasks between the head teachers' and the school counsellors' assessments about how true the statements were was quite big. The head teachers stated significantly more often that they had regular meetings in which they discussed the work done with the school counsellors and they planned further work. They also stated more frequently that they shared tasks with the school counselling service.

Both groups gave the highest score to the statement I often meet with the school counselling service / the head teacher outside scheduled regular appointments. This was expected, since it reflects the nature of school work, which requires daily responses to a variety of different situations, and any effective solution of newly arising situations necessitates cooperation with all the participants getting involved and contributing their shares promptly. That they also meet outside scheduled appointments 
is revealed by their responses to the statement I cooperate with the school counselling service / the head teacher mainly in boards - together with the manager, head teachers, assistants, etc., where both groups stated in large shares that the statements were not true or not true at all. This is important, since a study showed that more frequent meetings were associated with higher ratings of relationship quality, but the meetings did not need to be formalised in order to be effective (Duslak and Geier, 2016).

The school counsellors, interestingly, expressed a higher degree of agreement than the head teachers with the statement The plan for what needs to be done and how to do it is drawn up by the head teacher. The head teacher also decides who will do what. It seems that the school counsellors saw the head teacher as "first among equals", the person who decides what will be done in the school and who will do it, whereas the head teachers did not see themselves in that role quite as much. Perhaps the head teachers' responses suggest a higher degree of participatory leadership (cf. Dolgan, 2012), while the school counsellors did not notice it in practice to the same degree. This, too, concerns the issue of head

Table 4: The head teachers' and the school counsellors' assessments of the obstacles to their mutual cooperation

\begin{tabular}{|c|c|c|c|c|c|c|c|c|}
\hline \multirow{2}{*}{\multicolumn{3}{|c|}{$\begin{array}{l}\text { The assessments given by head teachers and } \\
\text { the school counsellors about obstacles to } \\
\text { cooperation }\end{array}$}} & \multicolumn{5}{|c|}{ Assessments of individual statements } & \multirow[t]{2}{*}{$\begin{array}{l}\chi^{2 \text {-test }} \\
\alpha\end{array}$} \\
\hline & & & \multirow{2}{*}{\begin{tabular}{|l|}
$\begin{array}{l}\text { No } \\
\text { obstacle }\end{array}$ \\
109 \\
$51.2 \%$ \\
\end{tabular}} & \multirow{2}{*}{$\begin{array}{l}\begin{array}{l}\text { Minor } \\
\text { obstacle }\end{array} \\
67 \\
31.5 \% \\
\end{array}$} & \multirow{2}{*}{$\begin{array}{l}\text { Obstacle } \\
30 \\
14.1 \% \\
\end{array}$} & \multirow{2}{*}{\begin{tabular}{|l|}
$\begin{array}{l}\text { Major } \\
\text { obstacle }\end{array}$ \\
7 \\
$3.3 \%$ \\
\end{tabular}} & \multirow{2}{*}{$\begin{array}{l}\mathrm{N} \\
213 \\
100.0 \%\end{array}$} & \\
\hline \multirow{2}{*}{$\begin{array}{l}\text { Lack of knowledge of each } \\
\text { other's work and tasks }\end{array}$} & $\begin{array}{l}\text { Head } \\
\text { teachers }\end{array}$ & $\begin{array}{l}\mathrm{f} \\
\mathrm{f} \%\end{array}$ & & & & & & \multirow[b]{2}{*}{$\begin{array}{l}6.890 \\
.075\end{array}$} \\
\hline & $\begin{array}{l}\text { School } \\
\text { counsellors }\end{array}$ & $\begin{array}{l}\mathrm{f} \\
\mathrm{f} \%\end{array}$ & $\begin{array}{l}112 \\
42.1 \%\end{array}$ & $\begin{array}{l}98 \\
36.8 \%\end{array}$ & $\begin{array}{l}36 \\
13.5 \%\end{array}$ & $\begin{array}{l}20 \\
7.5 \%\end{array}$ & $\begin{array}{l}266 \\
100.0 \%\end{array}$ & \\
\hline \multirow{2}{*}{ Work overload (both) } & $\begin{array}{l}\text { Head } \\
\text { teachers }\end{array}$ & $\begin{array}{l}\mathrm{f} \\
\mathrm{f} \%\end{array}$ & $\begin{array}{l}22 \\
10.3 \%\end{array}$ & $\begin{array}{l}50 \\
23.5 \%\end{array}$ & $\begin{array}{l}70 \\
32.9 \%\end{array}$ & $\begin{array}{l}71 \\
33.3 \%\end{array}$ & $\begin{array}{l}213 \\
100.0 \%\end{array}$ & \multirow{2}{*}{$\begin{array}{l}5.165 \\
.160\end{array}$} \\
\hline & $\begin{array}{l}\text { School } \\
\text { counsellors }\end{array}$ & $\begin{array}{l}\mathrm{f} \\
\mathrm{f} \%\end{array}$ & $\begin{array}{l}41 \\
15.4 \%\end{array}$ & $\begin{array}{l}70 \\
26.3 \%\end{array}$ & $\begin{array}{l}87 \\
32.7 \%\end{array}$ & $\begin{array}{l}68 \\
25.6 \%\end{array}$ & $\begin{array}{l}266 \\
100.0 \%\end{array}$ & \\
\hline \multirow{2}{*}{ Poor communication } & $\begin{array}{l}\text { Head } \\
\text { teachers }\end{array}$ & $\begin{array}{l}\mathrm{f} \\
\mathrm{f} \%\end{array}$ & $\begin{array}{l}148 \\
69.5 \%\end{array}$ & $\begin{array}{l}32 \\
15.0 \%\end{array}$ & $\begin{array}{l}21 \\
9.9 \%\end{array}$ & $\begin{array}{l}12 \\
5.6 \%\end{array}$ & $\begin{array}{l}213 \\
100.0 \%\end{array}$ & \multirow{2}{*}{$\begin{array}{l}9.058 \\
.029\end{array}$} \\
\hline & $\begin{array}{l}\text { School } \\
\text { counsellors }\end{array}$ & $\begin{array}{l}\mathrm{f} \\
\mathrm{f} \%\end{array}$ & $\begin{array}{l}154 \\
57.9 \% \\
\end{array}$ & $\begin{array}{l}68 \\
25.6 \% \\
\end{array}$ & $\begin{array}{l}26 \\
9.8 \% \\
\end{array}$ & $\begin{array}{l}18 \\
6.8 \% \\
\end{array}$ & $\begin{array}{l}266 \\
100.0 \% \\
\end{array}$ & \\
\hline \multirow{2}{*}{$\begin{array}{l}\text { Bad experiences of mutual } \\
\text { cooperation }\end{array}$} & $\begin{array}{l}\text { Head } \\
\text { teachers }\end{array}$ & $\begin{array}{l}\mathrm{f} \\
\mathrm{f} \%\end{array}$ & $\begin{array}{l}159 \\
74.6 \% \\
\end{array}$ & $\begin{array}{l}29 \\
13.6 \% \\
\end{array}$ & $\begin{array}{l}15 \\
7.0 \% \\
\end{array}$ & $\begin{array}{l}10 \\
4.7 \% \\
\end{array}$ & $\begin{array}{l}213 \\
100.0 \% \\
\end{array}$ & \multirow{2}{*}{$\begin{array}{l}2.301 \\
.531\end{array}$} \\
\hline & $\begin{array}{l}\text { School } \\
\text { counsellors }\end{array}$ & $\begin{array}{l}\mathrm{f} \\
\mathrm{f} \%\end{array}$ & $\begin{array}{l}196 \\
73.7 \% \\
\end{array}$ & $\begin{array}{l}45 \\
16.9 \% \\
\end{array}$ & $\begin{array}{l}12 \\
4.5 \%\end{array}$ & $\begin{array}{l}13 \\
4.9 \% \\
\end{array}$ & $\begin{array}{l}266 \\
100.0 \% \\
\end{array}$ & \\
\hline \multirow{2}{*}{$\begin{array}{l}\text { Different expectations from } \\
\text { mutual cooperation }\end{array}$} & $\begin{array}{l}\text { Head } \\
\text { teachers }\end{array}$ & $\begin{array}{l}\mathrm{f} \\
\mathrm{f} \%\end{array}$ & $\begin{array}{l}117 \\
54.9 \%\end{array}$ & $\begin{array}{l}56 \\
26.3 \%\end{array}$ & $\begin{array}{l}29 \\
13.6 \%\end{array}$ & $\begin{array}{l}11 \\
5.2 \%\end{array}$ & $\begin{array}{l}213 \\
100.0 \%\end{array}$ & \multirow{2}{*}{$\begin{array}{l}2.626 \\
.453\end{array}$} \\
\hline & $\begin{array}{l}\text { School } \\
\text { counsellors }\end{array}$ & $\begin{array}{l}\mathrm{f} \\
\mathrm{f} \% \\
\end{array}$ & $\begin{array}{l}134 \\
50.4 \% \\
\end{array}$ & $\begin{array}{l}84 \\
31.6 \% \\
\end{array}$ & $\begin{array}{l}30 \\
11.3 \% \\
\end{array}$ & \begin{tabular}{|l|}
18 \\
$6.8 \%$ \\
\end{tabular} & $\begin{array}{l}266 \\
100.0 \% \\
\end{array}$ & \\
\hline \multirow{2}{*}{$\begin{array}{l}\text { Differences in professional } \\
\text { views on work in the } \\
\text { classroom and with } \\
\text { students }\end{array}$} & $\begin{array}{l}\text { Head } \\
\text { teachers }\end{array}$ & $\begin{array}{l}\mathrm{f} \\
\mathrm{f} \%\end{array}$ & $\begin{array}{l}109 \\
51.2 \% \\
\end{array}$ & $\begin{array}{l}66 \\
31.0 \% \\
\end{array}$ & $\begin{array}{l}31 \\
14.6 \% \\
\end{array}$ & \begin{tabular}{|l|}
7 \\
$3.3 \%$ \\
\end{tabular} & $\begin{array}{l}213 \\
100.0 \%\end{array}$ & \multirow{2}{*}{$\begin{array}{l}7,078 \\
.069\end{array}$} \\
\hline & $\begin{array}{l}\text { School } \\
\text { counsellors }\end{array}$ & $\begin{array}{l}\mathrm{f} \\
\mathrm{f} \%\end{array}$ & $\begin{array}{l}127 \\
47.7 \%\end{array}$ & $\begin{array}{l}87 \\
32.7 \%\end{array}$ & $\begin{array}{l}29 \\
10.9 \%\end{array}$ & $\begin{array}{l}23 \\
8.6 \%\end{array}$ & $\begin{array}{l}266 \\
100.0 \%\end{array}$ & \\
\hline
\end{tabular}


teachers' and school counsellors' autonomy. We have already emphasised the importance of joint planning, monitoring and evaluation of the programme, and school counsellors and head teachers are partners, collaborators, both of whose participation is essential.

Mutual cooperation of different partners is always faced with obstacles that can present problems or challenges or opportunities for improvement. We enquired into what chief obstacles the head teachers and the school counsellors encountered in their mutual cooperation.

The question about the obstacles to cooperation between head teachers and school counsellors yielded very similar assessments provided by the two groups of respondents. Consequently, we found no statistically significant differences - except for the statement on Poor communication. The findings show that both the head teachers and the school counsellors stated that the biggest obstacle was work overload in both groups (given as the answer by two thirds of the responding head teachers and just over $58 \%$ of the school counsellors). They thought that the other obstacles were no real obstacles or only minor obstacles to mutual cooperation.

Poor communication and bad experiences of mutual cooperation were seen as an obstacle by fewer than $15 \%$ of the head teachers and a few more school counsellors (just over 16\% saw poor communication as an obstacle and just under $10 \%$ thought an obstacle lay in bad experiences of past mutual cooperation).

It is also worthy highlighting that more than a fifth $(21 \%)$ of the school counsellors saw obstacles in the lack of knowledge of each other's work and tasks. This implies that the school counsellors believed that the head teachers were insufficiently familiar with their work or that they did not know enough about the head teacher's work. Just over $17 \%$ of the head teachers also thought that a lack of knowledge of each other's work and tasks was detrimental to their cooperation. The responses are not surprising. Other studies, too, point to work overload and a lack of time for more and better cooperation (e.g. Finkelstein, 2009). Nonetheless, quality mutual cooperation requires debates, establishing cooperation and discussing the tasks that head teachers and school counsellors will undertake. Cooperative school culture begins to develop at the level of the head teacher's cooperation with their closest colleagues. It includes agreements, participation, shared responsibilities and joint planning of vision, goals and the activities that will lead towards the goals. Knowing each other's tasks and responsibilities seems to be the first step on the path of quality work (cf. Dahir et al., 2011, in Duslak and Geier, 2016; Edwards et al., 2014) and the professional development of both head teachers and school counsellors.

\section{CONCLUSION}

Many recent studies (Edwards et al., 2014; McCarty et al., 2014; Duslak and Geier, 2016) demonstrate that a strong head teacher-school counsellor relationship is a crucial component of meeting the vision, goals and well-being of the school. This implies that cooperation between head teachers and school counsellors goes beyond the well-being of individual students and does not focus solely on solving individual school problems. It is directed towards the assistance for and development of all students and the entire school. The findings of our empirical study show positive attitudes of both head teachers and school 
counsellors towards mutual cooperation. Both saw the cooperation as good or very good, the head teachers rated it even better that the school counsellors. Similar findings emerged when the respondents had assessed individual aspects of the cooperation. It is noteworthy, however, that the head teachers found more support in school counsellors than vice versa. Also, more of the head teachers said they saw school counsellors as partners than did the school counsellors. It thus remains to be seen how school counsellors' perception of the school leadership's support in their work could be strengthened and how head teachers could be encouraged to support the work of the school counselling service more. It is important that school counsellors are given sufficient professional autonomy, especially when work within their specific responsibilities is concerned. Indeed, professional autonomy has a consequence in a high degree of responsibility for the work done, which is perhaps not to everybody's liking. Since head teachers and school counsellors cooperate with the goal of the optimum development of the school as an institution and all its actors in mind (both teachers and everyone else entering the school space), their co-creation of vision, joint planning of goals, identification of opportunities and challenges for high quality work are really important. They share responsibilities; it is therefore important that their work is coordinated, that they support each other

\section{References}

1. Armstrong, S. A., MacDonald, J. H. and Stillo, S. (2010). School counselors and principals: Different perceptions of relationship, leadership, and training. Journal of School Counseling, 8(15), 1-27. https://eric.ed.gov/?id=EJ885153

2. Bela knjiga o vzgoji in izobraževanju v Republiki Sloveniji (2011). during the process of planning as well as monitoring and evaluating different activities. We see school counsellors, especially pedagogues, as head teachers' key consultants and collaborators, particularly in the areas of developing the school's educational concept, evaluation and self-evaluation, cooperation with other stakeholders (parents, the local community, various organisations, etc.) and support and assistance for students and teachers.

Having identified the main obstacles to mutual cooperation, we pointed out the key areas in which joint work should be built on. Both the head teachers and the school counsellors saw a serious obstacle in their work overload. Fewer respondents stressed as detrimental to their cooperation a lack of knowledge of each other's work and tasks, different expectations from mutual cooperation and differences in professional views on work in the classroom and with students. Joint work and planning as well as sharing responsibilities for activities are likely to remove at least some of the obstacles. When establishing cooperative school culture and climate, we should never ignore the significance of teamwork at various levels of school work and in cooperation between head teachers and school counsellors whilst looking for joint solutions, shared responsibilities and recognising each other's professional autonomy.

Ljubljana: Zavod RS za šolstvo. https://repozitorij.uni-lj.si/IzpisGradiva. php?id=69951

3. Bryan, J. A., Young, A., Griffin, D. and Holcomb-McCoy, C. (2018). Leadership Practices Linked to Involvement in School-FamilyCommunity Partnerships (A National Study). Professional School 
Counseling, 21(1), 1-13. https://doi. org/10.1177/2156759X18761897

4. Dolgan, K. (2012). Značilnosti vodenja $\mathrm{v}$ slovenskih osnovnih šolah. Andragoška spoznanja, 18(1), 10-27. https://doi.org/10.4312/as.18.1.10-27

5. Duslak, M. and Geier, B. (2016). Communication Factors as Predictors of Relationship Quality: A National Study of Principals and School Counselors (Featured Research). Professional School Counseling: 20162017, 20(1), 115-126. https://doi. org/10.5330/1096-2409-20.1.115

6. Edwards, L., Grace, R. and King, G. (2014). Importance of an Effective Principal-Counselor Relationship. Alabama Journal of Educational Leadership, 1, 34-42. https://files.eric. ed.gov/fulltext/EJ1097546.pdf

7. Finkelstein, D. (2009). A Closer Look at the Principal-Counselor Relationship. A Survey of Principals and Counselors. The College Board, American School Counselor Association, National Association of Secondary School Principals. https:// secure-media.collegeboard.org/digitalServices/pdf/nosca/a-closer-look_2. pdf

8. Greene, N. and Stewart, P. (2016). The School Counselor and the Principal: Keys to Successful Collaboration. The New Hampshire Journal of Education. http://nhje.plymouth. $\mathrm{edu} /$ ? article $=$ the-school-counselor-and-the-principal-keys-to-successful-collaboration

9. Gregorčič Mrvar, P. and Mažgon, J. (2017). The role of the school counsellor in school-community collaboration: the case of Slovenia. International Journal of Cognitive Research in Science, Engineering and Education,
5(1), 19-29. https://doi.org/10.5937/ IJCRSEE1701019G

10. Gregorčič Mrvar, P. and Resman, M. (2013). The role and significance of teamwork in the school environment (pp. 137-155). In: Radovan, M. and Kościelniak, M. (Ed.). Lifelong learning today: new areas, contexts, practices. 1st ed. Krakow: Jagiellonian University Press. https://www.wuj. pl/UserFiles/File/FRAGMENTY/ Lifelong\%20Learning\%20Todayfragment2.pdf

11. Harris, A. (2002). Distributed Leadership in Schools: Leading or Misleading Management in Education, 16(5), 10-13. https://doi. org/10.1177/089202060301600504

12. Harris, A. (2008). Distributed leadership: according to the evidence. Journal of Educational Administration, 46(2), 172-188. https://doi. org/10.1108/09578230810863253

13. Hertling, E. (2001) Retaining Principals. ERIC Clearinghouse on Educational Management (ERIC Digest No 147). https://files.eric. ed.gov/fulltext/ED454567.pdf

14. Janson, C., Militello M. and Kosine, N. (2008). Four Views of the Professional School Counselor-Principal Relationship:A Q-Methodology Study. Professional School Counseling, 11(6), 353-361. http://journals.sagepub.com/ doi/abs/10.1177/2156759X0801100601

15. Jeznik, K., Ermenc, K. S. and Mažgon, J. (2018). A festival as a pedagogical tool to promote inclusion in the community and in schools. Problems of education in the 21st century, 76(2), 159-174. http://oaji.net/articles/2017/457-1524597419.pdf

16. Lesar, I. (2018). Mapping inclusive education within the discipline of 
pedagogy. Comparative analysis of new study programmes in Slovenia. International journal of inclusive education, Online ed., 22. https://doi.org/1 $0.1080 / 13603116.2017 .1402376$

17. McCarty, D., Wallin, P. and Boggan, M. (2014). Shared Leadership Model for 21st Century Schools: Principal and Counselor Collaborative Leadership. National forum of educational administration and supervision journal, 32(4). http://www.nationalforum.com/ Electronic\%20Journal\%20Volumes/ McCarty,\%20Darla\%20Shared\%20 Leadership\%20NFEASJ\%20V32\%20 N4\%202014.pdf

18. Podgornik, V. and Vogrinc, J. (2017). The role of headteachers, teachers, and school counsellors in the system of quality assessment and assurance of school work. SAGE open, $\quad 7(2), \quad 1-13$. https://doi. org/10.1177/2158244017713239

19. Pont, B., Nusche, D. and Hopkins, D. (Ed.) (2008). Improving School Leadership. Volume 2: Case Studies on System Leadership. Paris: OECD. http://www.oecd.org/education/ school/44375122.pdf

20. Pont, B., Nusche, D. and Moorman, H. (Ed.) (2008). Improving School Leadership. Volume 1: Policy and Practice. Paris: OECD. https:// www.leadershipacademy.at/downloads/OECD_Improving_School_ Leadership_Volume_1.pdf

21. Programske smernice. Svetovalna služba v osnovni šoli. (2008). Ljubljana: Zavod Republike Slovenije za šolstvo. http://www. mizs.gov.si/fileadmin/mizs.gov.si/pageuploads/ministrstvo/Publikacije/ Programske_smernice_OS.pdf

22. Resman, M. (1999). Pojem in karakteristike šolskega svetovanja. In:
M. Resman, J. Bečaj, T. Bezić, G. Čačinovič Vogrinčič, and J. Musek, Svetovalno delo $v$ vrtcih, osnovnih in srednjih šolah (pp. 67-84). Ljubljana: Zavod RS za šolstvo.

23. Resman, M. (2004). Ravnatelj, vodenje in šolski svetovalni delavec. Vodenje $v$ vzgoji in izobraževanju, 2, 7-22.

24. Resman, M., Bečaj, J., Bezić, T., Čačinovič Vogrinčič, G. and Musek, J. (1999). Svetovalno delo v vrtcih, osnovnih in srednjih šolah. Ljubljana: Zavod RS za šolstvo.

25. Resman, M., Kroflič, R. and Bezić, T. (2000). Pedagog in pedagoško svetovanje. Šolsko svetovalno delo, V(3), 5-14.

26. Sagadin, J. (2004). Tipi in vloga študij primerov $\mathrm{v}$ pedagoškem raziskovanju. Sodobna Pedagogika [Journal of Contemporary Educational Studies], 55(4), 88-99.

27. School Autonomy in Europe. Policies and Measures. (2007). Brussels: Eurydice. http://eacea.ec.europa.eu/ education/eurydice/documents/thematic_reports/090EN.pdf

28. Schleicher, A. (2015). Schools for 21st-Century Learners. Strong Leaders, Confident Teachers, Innovative Approaches. International Summit on the Teaching Profession, OECD Publishing. https://doi. org/10.1787/9789264231191-en

29. Stone, C. B. and Clark, M. A. (2001). School Counselors and Principals: Partners in Support of Academic Achievement. NASSP Bulletin, 85(624), 46-53. https://doi. org/10.1177/019263650108562407

30. Šteh, B., Muršak, J., Mažgon, J., Kalin, J., and Gregorčič Mrvar, P. (2018). School - Home - Community: Inevitable Connections. Berlin: Peter Lang. In Print. 
Management, Vol. 24, 2019, Special Issue, pp. 89-106 P. Gregorčič Mrvar, M. Resman, J. Kalin, J. Mažgon: COOPERATION BETWEEN HEAD...

31. Študijski programi Oddelka za pedagogiko in andragogiko FF UL. http://www.pedagogika-andragogika. com/studij

32. Zakon o organizaciji in financiranju vzgoje in izobraževanja [Organization and Financing of Education Act] (2017). http://imss.dz-rs.si/ imis/8192c66537c8af5d5e27.pdf
33. Wingfield, R. J., Reese, R. F., and West-Olatunji, C. A. (2010). Counselors as Leaders in Schools. Florida Journal of Educational Administration \& Policy, 4(1), 114130. https://eric.ed.gov/?id=EJ911435 


\section{SURADNJA IZMEĐU RAVNATELJA I PROFESIONALNIH ŠKOLSKIH PEDAGOGA U SLOVENSKIM ŠKOLAMA}

\begin{abstract}
Sažetak
$U$ ovom se radu teorijski i empirijski predstavljaju obilježja suradnje između ravnatelja $i$ školskih pedagoga. Distribuirano liderstvo podrazumijeva da ravnatelji ne vode škole pomoću školskog osoblja, već zajedno s njima, pri čemu školski pedagozi imaju važnu ulogu. Različite istraživačke studije ukazuju da je odnos između ravnatelja i školskog pedagoga ključan za ostvarivanje vizije, ciljeva i dobrobiti u školi. Rezultati ovog istraživanja, provedenog među ravnateljima i pedagozima, pokazuju da obje skupine imaju pozitivne stavove prema međusobnoj suradnji. Obje skupine, također, smatraju da je postojeća suradnja dobra ili vrlo dobra, a ravnatelji je
\end{abstract}

ocjenjuju kao još bolju. Zanimljivo je spomenuti da su ravnatelji imali veću podršku od strane pedagoga, negoli je to moguće primijetiti u obrnutom slučaju. Također treba napomenuti da je veći udjel ravnatelja vidio partnere $u$ školskim pedagozima, negoli se isto može reći i za suprotan slučaj. Stoga ostaje otvorenim pitanjem kako školski pedagozi percipiraju ravnateljsku podršku svom poslu te kako bi ih se ravnatelje moglo ohrabriti na veću podršku pedagozima, kako bi se navedeni odnos mogao razvijati u recipročnom smislu te međusobno podupirati obavljanje obaju poslova.

Ključne riječi: distribuirano liderstvo, ravnatelj, pedagog (školski savjetnik), suradnja 